Kuat T. (2018). Implementation of edupreneurship through the teaching factory in vocational high school of hotel accommodation: Case study at SMK N 6 Yogyakarta. Journal of Vocational Education Studies, 1(1), 7-12. DOI: https://doi.org/10.12928/joves.v1i1.590.

\title{
Implementation of edupreneurship through the teaching factory in vocational high school of hotel accommodation: Case study at SMK N 6 Yogyakarta
}

\author{
Tri Kuat \\ Universitas Ahmad Dahlan, Jl. Pramuka 42, Sidikan, Yogyakarta, Indonesia \\ E-mail: tri.kuat@mpv.uad.ac.id
}

\begin{abstract}
The purpose of this study is to know, to describe, and to analyze the implementation of edupreneurship through teaching factory in the vocational high school (SMK) majoring in hotel accommodation program skill. The research method used in this research is the qualitative method. This method is intended to know deeply in the implementation of edupreneurship through teaching factory in SMK. This research started with the observation of edupreneurship activity through teaching factory at SMK N 6 Yogyakarta. The data was collected by conducting in-depth interviews with informants who are directly involved in edupreneurship activities. The result of this research is the implementation of edupreneurship through teaching factory in terms of learning, there is commitment and basic principle which run by the school but not yet optimal. There are still significant obstacles, especially related to the work culture that is applied not in accordance with the procedures of business and industry (DUDI), educators who have not understood the culture of DUDI, facilities, and infrastructure that do not meet the DUDI standards, the cooperation between SMK and DUDI is still weak, and the regulation of the Supreme Audit Agency (BPK) which requires the use of state-owned goods as a form of state income.
\end{abstract}

Keywords: Edupreneurship, Entrepreneurship, Teaching factory.

\begin{abstract}
Abstrak
Tujuan dari penelitian ini adalah untuk mengetahui, mendeskripsikan dan menganalisis implementasi edupreneurship melalui teaching factory di program keahlian perhotelan SMK. Metode penelitian yang digunakan dalam penelitian ini adalah metode kualitatif. Metode ini dimaksudkan untuk mengetahui secara mendalam dalam pelaksanaan edupreneurship melalui teaching factory di SMK. Penelitian ini dimulai dengan pengamatan aktivitas edupreneurship melalui pabrik pengajaran di SMK N 6 Yogyakarta. Data diperoleh dengan melakukan wawancara mendalam dengan informan yang terlibat langsung dalam kegiatan edupreneurship. Hasil dari penelitian ini adalah penerapan edupreneurship melalui teaching factory dalam hal pembelajaran terdapat komitmen dan prinsip dasar yang dijalankan oleh sekolah tetapi belum optimal. Masih ada kendala signifikan, terutama terkait dengan budaya kerja yang diterapkan tidak sesuai dengan prosedur bisnis dan industri (DUDI), pendidik yang belum memahami budaya DUDI, sarana, dan infrastruktur yang tidak memenuhi standar DUDI, kerjasama antara SMK dan DUDI masih lemah, dan peraturan Badan Pemeriksa Keuangan (BPK) yang mewajibkan penggunaan barang-barang milik negara sebagai bentuk pendapatan negara.
\end{abstract}

Kata Kunci: Edupreneurship, Entrepreneurship, Teaching factory.

\section{INTRODUCTION}

Edupreneurship is an activity that is emphasized on creative or innovative efforts undertaken by schools to gain school achievement and increase income. Implementation can be through teaching factory and business center. Through the teaching factory by means of students performing similar or almost the same learning activities conducted in business and industry, the teaching factory becomes a learning concept in the real state to bridge the competency gap between the knowledge provided by the school and the needs of the industry. Learning through the teaching factory aims to foster the character and work ethic 
(discipline, responsibility, honest, cooperation, leadership, etc.) that the business world and industry needs and improve the quality of learning outcomes from simply providing competence (competency-based training) leading to learning that provides the ability to produce goods/services (production-based training).

The success of teaching factory where the school can provide a place of practice like the actual industry, and be in the school environment so that students in practice according to standards, procedures and work culture of the business and industry. SMK tourism skills program as a place of practice is Edotel. Edotel is an educational hotel (teaching hotel), which in the day-to-day activities serve guests and as a place to stay. The management is done by a competent professional managing a hotel.

In accordance with the problems and facts in the field to realize the SMK that has the attitude and entrepreneurship spirit through edupreneurship, then this study intends to examine and analyze in depth how the description of the implementation of edupreneurship through teaching factory. The research was conducted in SMK N 6 Yogyakarta. This location was chosen because the SMK has implemented edupreneurship through a hospitality business that has been developed as a student practice. Based on these reasons can be formulated problems as follows: How to implement edupreneurship through teaching factory at SMK of hotel accommodation program skill in SMK N 6 Yogyakarta. The purpose of this research is to knowing, describing, and analyzing the implementation of edupreneurship through teaching factory at SMK N 6 Yogyakarta.

\section{The Concept of Edupreneurship}

Edupreneurship is a part of entrepreneurship that is implemented in the field of education. Entrepreneurship is a creative or innovative effort by seeing or creating opportunities and realizing them into something that has added value (economic, social, etc.). Entrepreneurship in the social field called sociopreneurship, in the field of education called edupreneurship, in the internal company called interpreneurship, in the field of technology business called technopreneurship (Alim, 2010).

Oxford Project (2012) describes edupreneurship as a school that always innovates systemically, transformational change, regardless of existing resources, current capacity or national pressure in order to create new educational opportunities and excellence. The concept of edupreneurship is focused on the efforts made by schools creatively and/or innovatively to gain school excellence in the form of achievement and also increase income (Mulyatiningsih, Sugiyono, \& Purwanti, 2014).

\section{Teaching factory}

Teaching factory is a concept of contextual learning that makes students' learning approach to actual work situations and conditions. Teaching Factory is an industrial replica, owns equipment with industry, applies operational standard procedure same with industry so production of goods and services equal to the industry. Teaching Factory is expected to bridge the required competency gap industry with the competencies learned in school.

In general, teaching factory aims to train disciplined students, improve students' skill competence, instill mental work to be easily adapted to the situation and condition of the industry, mastering the managerial field and producing products of industry standard quality (Darmawan, Sumitro, \& Djasmi, 2009).

Learning model is a learning activity that is designed or developed by using certain learning patterns. Learning patterns can describe the activities between teachers and learners in realizing learning conditions or environmental systems that cause the learning process. Learning patterns explain the characteristics of a series of activities undertaken by

Kuat T. (2018). Implementation of edupreneurship through the teaching factory in vocational high school of hotel accommodation: Case study at SMK N 6 Yogyakarta. Journal of Vocational Education Studies, 1(1), 7-12. DOI: https://doi.org/10.12928/joves.v1i1.590. 
teachers with learners (Joyce, Calhoun, \& Hopkins, 2008). Device Network Application (DNA) Initiative is a curriculum developed for vocational school with difficulty level tiered. DNA Initiative is a learning model that equips students in the field of hardware-based Mobile, network and software applications.

The curriculum has a central position in the entire educational process. The curriculum directs all forms of educational activity for the achievement of educational goals. The curriculum "prescribes (or at least anticipates) the result of instruction" (Finch \& Crunkilton, 1999). The curriculum is also an educational plan, providing guidance and guidance on the type, scope, and sequence of educational content and processes.

The concept of curriculum develops in line with the development of educational theories and practices. The curriculum is not just a collection of subjects, but the curriculum emphasizes more on learning experiences. The commonly accepted definition of the curriculum has changes from content of course of study and list of subject and courses to all the experiences which are offered to learners under the auspices or direction of the school (Doll, 1992).

Competence of vocational students should be able to balance the development of the business world and industry. If not then it will only create unemployment that will increase every year. Unemployment at the VHS level is also the highest number at the time. According to the Central Bureau of Statistics (BPS), that unemployment in 2016 amounted to $7,024,172$. While the number of cannot be accommodated in the company, while for awareness of opening a business or self-entrepreneurship is also still low. In Indonesia entrepreneurial figures score 21.2 or are on the order of 90 out of 137 countries (GEDI, 2017). This shows the importance of building a high work ethic by implementing entrepreneurship so that unemployment at the vocational school level can be reduced.

Technology education is an integral component that is important in the world of education as a whole. This is because technology has penetrated into every space of human life. The so-called technological literacy for the (educated) community is an integral part of the overall educational orientation (Stevenson, 2003).

\section{RESEARCH METHOD}

The research method chosen is qualitative research method. According to Straus \& Corbin (1990) on a qualitative approach, the data collected generally shaped words, images and not the numbers, even if there are numbers only as supporting characters. The data includes interview transcripts, field notes, photographs, personal documents, notes, and other records. It is for this reason that a qualitative-descriptive approach is chosen. The qualitative approach also refers to the explanation of Straus \& Corbin (1990) explaining that qualitative research that explains the beliefs of researchers based on the research experience and the nature of the problem. The same thing is also expressed by Moleong (2007) research is a procedure of data collection that produces descriptive data in the form of written or oral words of the people and behavior that can be observed.

Research on the implementation of edupreneurship through teaching factory is done in SMK N 6 Yogyakarta. The reason for choosing this location is because SMK N 6 Yogyakarta is a vocational school, which already has edotel as vehicle teaching factory in creating student competence.

The objectives of this study include school principals, vice principal of curriculum, productive teachers, students, SMK N 6 Yogyakarta. This target is considered the most understanding and know related to the implementation of edupreneurship through teaching factory in school.

Kuat T. (2018). Implementation of edupreneurship through the teaching factory in vocational high school of hotel accommodation: Case study at SMK N 6 Yogyakarta. Journal of Vocational Education Studies, 1(1), 7-12. D0I: https://doi.org/10.12928/joves.v1i1.590. 
Qualitative research requires a research focus, the determination of a research focus is needed so that a researcher will know exactly which data needs to be collected and which data may be interesting but irrelevant, not necessarily included in the data being collected (Moleong, 2007). The focus of this research includes the following: (1) Education policies implemented by schools either from the central level or from the school; (2) Map of problems and obstacles in the implementation of edupeneurship through teaching factory activities in schools; (3) The effort did in improving the success of the implementation of edupreneurship through teaching factory activities in schools; (4) Criteria for student success after doing teaching factory activity in edotel. To collect data and information as needed to support this research is used with various techniques, namely: interview technique, observation, and document study.

The technique of examining the validity of the data using triangulation technique is a technique of checking the validity of data that utilizes something else outside the data for the purposes of checking or as a comparison against that data. In triangulation techniques in this study used based on the source (Moleong, 2007).

Data analysis method used in this research is descriptive qualitative analysis method, with interactive analysis model by Miles \& Huberman (1994). He argues that the activity in qualitative data analysis is done interactively and continuously to complete, so the data is saturated. Data saturation sizes are indicated by no new data or information being retrieved. Activities in the analysis include data reduction, data presentation, and conclusion drawing/verification.

\section{RESULTS AND DISCUSSION}

Implementation of edupreneurship through teaching factory at SMKN 6 Yogyakarta. only emphasize on aspects of learning, include: (1) The process of learning skills or skills as one of the subjects. Hospitality skills program at SMK N 6 Yogyakarta skill learning is included in entrepreneurship practice subject. Learning process with edupreneurship through teaching factory is a learning model that is expected to help and support students in having the skills and skills as part of owned. With practical learning, it is expected that students will easily master the competence. Competence achieved is a repetitive work so that students can understand and become the character of work. (2) Entrepreneurship learning that is designed and implemented based on real job procedures and standards. Learning like in the real workplace by using edotel as a place of learning has provided a learning process that puts forward direct practice in the workplace, for which the ability of students to work directly has gone through the procedures applied. Students of hospitality skills program become skilled and skilled with teaching factory program. (3) Development of student soft skills, which includes intellectual, emotional, spiritual, and social intelligence. SMKN 6 Yogyakarta, in this case, has supported all the necessary school facilities in the growth of soft skills of students. Available facilities, such as edotel, computer labs, language laboratories, beauty salons, sports fields, and school mosques

The implementation of the hotel's hospitality skills program activities at SMK N 6 Yogyakarta is still hampered in the process of formulation, planning, development and edotel finance which is still problematic, not to mention the issue of supervision related to the audit of the State Audit Board (BPK) which requires every state facility used must be part of state revenue. This is what hampered the teaching factory teaching process, in addition to technical readiness on the role of teachers and cooperation with the business and industry (DUDI) especially get more representative practice place is still limited, so there are still students who work / industry practice not in accordance with its competence.

Kuat T. (2018). Implementation of edupreneurship through the teaching factory in vocational high school of hotel accommodation: Case study at SMK N 6 Yogyakarta. Journal of Vocational Education Studies, 1(1), 7-12. D0I: https://doi.org/10.12928/joves.v1i1.590. 
In addition, the work culture is not as DUDI demands, facilities and infrastructure have been left behind with the demands of DUDI.

This study emphasizes on edupreneurship especially the learning process, not paying attention to other dimensions. Results of research at SMKN 6 Yogyakarta. In general, it can be said the results of research related to the implementation of edupreunership through teaching factory shows the commitment of institutions or vocational schools in learning kewirausaahn. This is evidenced by the entrepreneurial empowerment that is intended for all levels, this fact proves entrepreneurial subjects have strategic meaning and for learners and institutions. SMKN 6 Yogyakarta in principle has a basic principle of entrepreneurship learning with industry base because it has edotel as a place of student practice. This is in accordance with the first Proser's argument that "Vocational education will be efficient if the environment in which the student is trained is an environmental replica of which he will work later" (Prosser \& Quigley, 1949).

The development of character embodied in the form of spirit and hard work, high motivation, creativity, problem-solving. The value becomes the color in the development of soft skills needed in the development of the personality of the learners. Based on the implementation procedure there are important things to be considered in the implementation of edupreunership. The teaching factory program is a positive step to develop the entrepreneur spirit, in the hope that graduate school vocational school can be a regional asset and problem solving to the problem of human resources.

\section{CONCLUSION}

Implementation of edupreneurship through teaching factory in terms of learning already existing commitment and basic principles that are run by schools but not optimal. There are still obstacles, especially related to the work culture that is applied not in accordance with the procedures of business and industry (DUDI), educators who have not understood the culture of DUDI, facilities, and infrastructure that do not meet DUDI standards, the cooperation between SMK and DUDI is still weak, as well as BPK regulations requiring the use of state-owned goods as a form of state income.

\section{REFERENCES}

Alim, I. (2010). Peranan ITB dalam Pengembangan Kewirausahaan. Bandung: Institut Teknologi Bandung.

Darmawan, I. N. G., Sumitro, B., \& Djasmi, S. (2009). Evaluasi manajemen teaching factory pada unit produksi training hotel Sekolah Menengah Kejuruan Kridawisata Bandar Lampung. Bandar Lampung: FKIP Universitas Lampung.

Doll, R. C. (1992). Curriculum improvement: Decision making and process. Massachusett: Allyn \& Bacon.

Finch, C. R., \& Crunkilton, J. R. (1999). Curriculum development in vocational and technical education. planning, content, and implementation. Massachusett: Allyn and Bacon.

GEDI. (2017). Global Entrepreneurship Index 2017. Retrieved from: https://thegedi.org/global-entrepreneurship-and-development-index/

Joyce, B., Calhoun, E., \& Hopkins, D. (2008). Models of learning, tools for teaching. Singapore: McGraw-Hill Education.

Miles, M. B., \& Huberman, A. M. (1994). Qualitative data analysis: An expanded sourcebook. Thousand Oaks: Sage Publications.

Kuat T. (2018). Implementation of edupreneurship through the teaching factory in vocational high school of hotel accommodation: Case study at SMK N 6 Yogyakarta. Journal of Vocational Education Studies, 1(1), 7-12. DOI: https://doi.org/10.12928/joves.v1i1.590. 
Moleong, L. J. (2007). Metodologi Penelitian Kualitatif Edisi Revisi. Bandung: Remaja Rosdakarya.

Mulyatiningsih, Sugiyono, \& Purwanti, S. (2014). Pengembangan Edupreneurship Sekolah Kejuruan. Yogyakarta: Universitas Negeri Yogyakarta.

Oxford Project. (2012). Leading through Edupreneurship. Oxford: Oxford Community Schools.

Prosser, C. A., \& Quigley, T. H. (1949). Vocational Education in a Democracy. Chicago: American Technical Society.

Stevenson, J. (2003). Examining cognitive bases for differentiating technology education and vocational education. In Initiatives in Technology Education-Comparative Perspectives: Proceeds of the American Forum (pp. 194-206).

Straus, A. L., \& Corbin, J. M. (1990). Basic of Qualitative Research Grounded Theory and Techniques. Newbury Park Calif: Sage Publications.

Kuat T. (2018). Implementation of edupreneurship through the teaching factory in vocational high school of hotel accommodation: Case study at SMK N 6 Yogyakarta. Journal of Vocational Education Studies, 1(1), 7-12. DOI: https://doi.org/10.12928/joves.v1i1.590. 